\title{
Sustainable Valorization of Vernacular Patrimony in European and American Space. Examples of Good Practices of Outdoor Museum Architecture
}

\author{
Astrid Isabela Bogdan \\ “Dimitrie Cantemir” Christian University, Bucharest, Romania, astrid.isabela@yahoo.com
}

\begin{abstract}
Lato sensu, we will bring together Architecture, Education Sciences and Legal Sciences in developing a good practice guide on the remodeling of outdoor museums, which will attempt to sustainable value the vernacular heritage. Moreover, considering that architecture is a defining component of cultural heritage, we believe that a work which aims to redefine a key concept for the world heritage is a necessary initiative for the museum environment, also the valorization of cultural heritage. Stricto sensu, we intend to start from some studies and examples of good practices, relying on contemporary cases. In addition, we will start building a discourse on interdisciplinarity, because for an outdoor museum it is not needed only a curator, but a whole group of specialists who could bring new elements of attractive interactivity to a more diverse audience.
\end{abstract}

KEYWORDS: $21^{\text {st }}$ century, architecture, cultural patrimony, interdisciplinarity, law

\section{Introduction}

Taking into account the thematic framing of the paper, we propose the creation of a novel study by which to use the existing interdependence between domains that at first sight do not seem to have a common ground.

Lato sensu, we will bring together Architecture, Education Sciences and Legal Sciences to develop a good practice guide on the remodeling of open-air museums, as well as the formation of a new open-air museum structure that will try to harness the vernacular heritage. Moreover, considering that architecture is a defining component of cultural heritage, we believe that a work that aims to redefine a key concept for world heritage through this area, is a necessary initiative for the museum environment, the complex valorization of the cultural heritage, both in a future internal context, as well as at an external level. In addition, we emphasize that architecture is one of the areas that could make real contributions to this issue.

Stricto sensu, we will emphasize the importance of certain key concepts such as: History of Art, Heritage, Museum Education etc. by conducting extensive case studies on our way to valorizing projects aimed at research into open-air museums in the European and American space alike. Of course, there are endeavors in this direction, but the foundation is not a solid one, given the lack of genuine interdependence between architecture, museology and the legal field. In addition, we will try to start building a discourse of interdisciplinarity, because for the realization of an open-air museum it is not only a museum designer, but a whole team of scenographers, architects, craftsmen and so on. In addition, besides encouraging the construction of authentic and specific edifices of certain periods of history, we consider it necessary to include certain elements, for example the gastronomic component, which would only bring new and new elements of interactivity appealing to a wide audience.

Of course, there are many studies on the value of museums in the open air, but a study covering both architecture, legal and education issues would make a good contribution, representing seeds for a fruitful future in this field.

Therefore, each part of the paper will focus on a particular issue, so it is difficult for us to recognize the contribution of certain authors, in this case, of some fundamental works on which we will conduct certain research directions. However, we will try to conduct a fair analysis and corroboration of all the sources and resources that have emerged during the research to bring a more objective view on the topic chosen for research. Moreover, we consider not only an analysis of the 
sources already existing in the literature, but also a more active interaction with people from different fields that could help to complete the present study.

\section{Resources}

We believe that such a study may be based on some working tools, such as:

- Questionnaires

- Interviews

- Workshops

- Temporary exhibitions

- Case studies etc.

By doing a fair analysis of the sources, we can say that most of the papers reviewed are based on new visions of understanding some key concepts for this paper, such as the idea of contemporaryity, education, exposure etc.

Choosing the basics was not at all random, but essentially based on the interdependence of the chosen subject and their content. Basically, the sources, whether primary or secondary, have as substance the significance of the theme, as well as the right endeavor to achieve new directions in the exposure types specific to the open air museum.

As far as the research methodology is concerned, we propose to use a suite of resources that help the presentation of a complete picture on the realization of a new type of exposure. Moreover, we want through the study visits, interviews and questionnaires to find both, the needs of the public and the various opinions of specialists from different fields that could make a real contribution to redefining the chosen concept. In addition, we support ab initio, the collaboration between people with different visions.

\section{New items and originality}

Creating a new vision on the architecture concept of the open air museum, the directions and trends of contemporary museum education in the European and American space, the creation of new working methods for the permanent and temporary exhibitions of museums, in this case of open-air museums. Practically, we will try not only to redefine this concept by rebuilding some sections of existing museums but we will try to set up, with architects and other specialists, the formation of a new pattern of an open-air museum. In other words, we will try to bring new valences to this type of exposure by forming a study based on the interdependence of more or less auxiliary domains.

The basis for these elements will be both the resources mentioned above and the literature. Moreover, if for the legal domain we are going to use the legislation and doctrine, both internally and internationally, for the education sciences we will generally point to specialized studies based on alternative pedagogies, such as Waldorf pedagogy (Waldorf Federation of Romania 2010).

Another author who has very well defined the term of contemporaryity is Boris Groys, realizing an interdependence between philosophy, art history and psychology.

Also, we can not deny Dr. Howard Gardner's contribution, which has made important contributions in the field of education and psychology, by developing a theory of multiple intelligences that supports the existence of many types of intelligence present for all people.

As for the directions and tendencies in museology, we could mention important authors, such as: Ioan Opriș, Eva Mârza, Radu Florescu, Florentina Nițu, Corina Nicolescu, Claudia Cleja, Timothy Ambrose, Kenneth Hudson etc. (Niţu 2005).

Generally, the present work proposes, in a first working hypothesis, to achieve a fair understanding of the public's view of cultural events in the country, especially with the term museum, and this will, initially, be done using a questionnaire.

In the following, we have proposed that, on the basis of some research, we should conceive the plan of an unprecedented exhibition. Also, we are trying to create series of atypical temporary exhibitions (Manega 2010). 


\section{Distribution in time of an open-air museum through the point of view of two visions}

In the first stage, we will focus on documentation. Thus, we will analyze the written sources and we will also make field research, both on the territory of certain European states and on some territories in the American space.

If we try to propose a synthesis of case studies on the directions and trends in contemporary museology, we notice that most of the attempts either become replicas of global exposure exercises or remain anchored in the old methods of exposure specific to a rigid speech.

Regarding the development of directions and trends in contemporary museology, we can see a fair change in the discourse, in the sense that most types of exposure address all the senses we are endowed with. In fact, a complete museum will consider, in addition to classical - virtual speech, also objects that invite the viewer to contemplate by other methods that stir up, for example, the olfactory sense. Although these types of exposure are not found in all museums in Romania, we have the full confidence that in the near future they will find the right resources for making a complete speech, that targets not only a certain audience, that wishes to bring the viewer by all means existing, to a fair and clear understanding.

Of course, there are a lot of typical examples of interactive museums that are mostly found in contemporary times, thanks to the rigorous efforts that have been put into practice over time and have contributed through examples of authentic practices, both at European and American level (Museosophia 2014).

Taking into account, as a case study in the European space, regarding the territory of Romania, we can say that, gradually, an improvement of the exposure process is attempted. Moreover, one can observe the desire to equate, to a certain extent, the exposure exercises made in other states through various methods of interactivity, elements, of course, with a novelty character for us.

So, despite the perceptible discrepancy between exposures in Romania and other countries, we can see some successes.

Of course, stage II consists of centralizing the documentation and use of certain resources (interviews, questionnaires, study visits, etc.) applied on both territories.

We believe that before you start building a concept, project, exhibition, temporary or permanent, it is fundamental that in a certain period of time you can find your inner and outer resources in truly discovering the needs of the audience you want to address to. In this sense, we intend to carry out a research project at the municipal level, initially, so that we can understand the needs of young people.

For example, the questionnaire is a first step towards awareness of certain impediments regarding young people visiting exhibitions. At first glance, we can see that in the vision of young people of all ages, the museum is a concrete, well-defined space where time stays on the spot, like an hourglass, in order to represent a formal or less formal speech idea. Basically, this questionnaire is the first step in starting an initiative in rediscovery of the museum and, implicitly, of permanent and temporary exhibitions in Romania.

The third stage will consist of analyzing the results, as well as interpreting them. Furthermore, we will draw some guidelines on the importance of architecture and, implicitly, of architects in complex museum activities, and finally we can draw a series of conclusions and, of course, lender ferenda proposals.

For an exhibition, whether permanent or temporary, to bring a coherent message decipherable to the public, we believe that it takes a whole team and not just a museographer to assign all of its tasks (Groys 2010). Of course, it is a commendable thing, but for a concept to be perfect, more visions are needed. So, through this study, we want to bring to the forefront the importance of other actors in the process of creating an exhibition. For example, for an open-air museum, the involvement of an architect, a craftsman and even a set designer is fundamental (George 2015).

Perhaps just a research of different fields at first glance would help a museographer/curator to make a coherent and clear discourse. For example, he could work with educators and psychologists to help him understand certain needs or priorities in the life of any young person, or with an 
architect and a set designer to bring an authentic atmosphere that supports the exhibition concept. Practically, this may be a first step towards a successful exhibition speech that would get easier to the heart of young people.

A simple concept of a permanent or temporary exhibition can reach the general public only through a fair attempt to understand the latter, because each experience, each concept, each exhibit has an identity, and each visitor can identify himself more or less with it. Actually, as an actor is also the exhibit, and the exhibition discourse is the script if you want, while the curator is like the director.

Therefore, the role of a curator is to understand the one he is addressing, to find the way to express the message as authentic as he can, and at the same time as easily perceived by the latter. Moreover, it is essential that every curator puts the exhibit in the spotlight, so that he unfolds completely, freely, in front of the viewer.

Moreover, perhaps a director has more courage than a curator, to display controversial themes, up-to-date themes in a more authentic way, and this message can be more easily perceived by a young man than a loaded exhibition with elements that in many young people's vision are of the past, the field of history that, although deserving of all our attention, is lost in the past, a past that may sometimes merge with the present and the future. However, in most cases, the museum is a place where you often go in an organized setting and not at all on your own initiative. Therefore, one of the aims of this work is the formation of activities that make up a static museum, a museum of all, a living museum that through its temporary exhibitions creates workshops, practically extensions, of the chosen concept.

The mobility of people to cross the threshold of museums is quite small on our territory, but we hope that, with the changes that have occurred, people will turn their attention to exhibitions (Steiner 1996).

If we look more closely at the types of exposure that unfolds abroad, we can observe that the exhibition discourse seizes new and new nuances. Moreover, the museum captures new and new definitions for the people and becomes, practically, a place where people halt even for a few moments in their free time with openness, enthusiasm and pleasure. As a matter of fact, like our malls, exhibitions constantly attract people from outside, people of various ages who have not lost their thirst for knowledge. In addition, the museum for them is not a space forgotten by the authorities it is a living space that invites everyone to reflection, to search, to self-knowledge.

If we were to compare the speeches of museums in Romania with those from outside the border, we would notice a huge discrepancy. Moreover, the public in Romania is tempted and often warned that they must keep their distance from the exposed objects.

We all know the warnings that are, of course, also found abroad, and that urge us to keep the distance and not touch the exhibits. This first exhortation, which is rather a warning in the true sense of the word, makes the visitor a simple child to whom Freedom is restricted and which is controlled in one sense or another by an authority.

\section{Sustainable valorization of vernacular patrimony in European space and American space}

Lato sensu, in order to speak about the patrimony in this case, we must bear in mind that at European level there are a number of documents that help this area, but their provisions are applied according to the specificity of each state. For example, in order to talk about sustainable values in the Romanian space, it is necessary to take into account the fact that vulnerability finds its genesis in the depletion of resources, focusing on their preservation, and a key in this sense consists in a good merge of the practical and the legal domain. Moreover, we need to mention some normative acts with a vital role in this area of interest:

- Decision no. 230 of 4 March 2003 on the delimitation of biosphere reserves, national parks and natural parks and the constitution of their administrations

- Law no. 5 of 6 March 2000 on the approval of the National Territory Planning Plan Section III - Protected Areas 
- Law no. 123 of 30 May 2017 for amending and completing the Law no. 182/2000 on the protection of the national mobile cultural heritage

- Order of the Minister of Culture and Religious Affairs no. 2185/2007 for the approval of the Norms for classification of museums and public collections etc.

Stricto sensu, norms and doctrines weave with jurisprudence, but in this case we appeal not only to court cases, but to examples of good practice in the field of museography. In addition, we will in the future attempt to analyze the application of norms in open-air museums in Romania, as well as to draft various proposals of the law ferenda in order to complete the currently inadequately enacted norms.

În comparație cu legislația din spațiul european, pe teritoriul american se pot observa unele practici mult mai diferite, însă nu putem recunoaște că de multe ori ne lăsăm inspirați reciproc.

Compared to European space legislation, some more different practices can be seen in US territory, but we can not recognize that we often leave each other to get inspired by the other.

However, the American vernacular heritage is in a continuous metamorphosis, a metamorphosis that extends externally, tending to become, through examples of good practice, a real landmark for a multitude of factors involved internationally.

\section{Conclusion}

Therefore, looking at the elements of vulnerability and identity on the territory of two beautiful worlds will be a fundamental element of the chosen theme, although it is a real challenge, we consider that this step is just an extension of research that has its own thirst of knowledge.

\section{References}

George, Adrian. 2015. „10 Tips for Aspiring Curators From Adrian George.” Artnews. Available at https://news.artnet.com/art-world/10-tips-for-aspiring-curators-from-adrian-george-246164.

Groys, Boris. 2010. Comrades of time. Pavilion - journal for politics and culture. Bucharest.

Manega, Miron. 2010. „The profession of curator.” Certitudinea.ro. Available at http://www.certitudinea.ro/articole/arte-vizuale/view/meseria-de-curator-nu-se-studiaza-dar-se-practica.

Nițu, Florentina. 2005. Auxiliary sciences, geography and historical demography. Numismatics and Archeology, Ministry of Education and Research. Project for Rural Education.

Steiner, Rudolf. 1996. Theosophy. Bucharest: Publisher Arhetip.

Waldorf Federation of Romania. 2010. "Euritmia." Waldorh.ro. Available at http://waldorf.ro/euritmia/.

Museosophia. 2014. "Types of exhibitions. Concept and Museum Technology.” Ethnography and Folk Art Museum, Tulcea. Available at https://museosophia.wordpress.com/2014/07/09/tipuri-de-expozitii-concept-si-muzeotehnica/. 